\title{
DIGITAL TRANSFORMATION IN THE MARKET OF ROAD FREIGHT TRANSPORTATION
}

\section{Horbenko Alexandra ${ }^{1}$}

DOI: https://doi.org/10.30525/978-9934-571-78-7_4

Abstract. In the digital age, information products play an important role in a customer-oriented approach. As it was noted, Baron R., Ziris M., Zintel E., Mikulla D. in their study: Digital platforms in freight traffic "companies can get three benefits from new opportunities that digitization can offer": increase cost efficiency, introduce new service offering, changing the way of doing business. Speaking of new service offering imply digital freight exchanges (DFEs). This is the most talkedabout example of logistics platforms at present. The purpose of the article is to study the structure and the capacity of digital transformation at Ukrainian market of road freight transportation in the global context. Based on the use of statistical methods, questionnaires, mail survey and personal interviews the main digital transformation trends at the market of road freight transportation are determined. The research has determined the shares of expeditionary and dispatch services provided by transportation marketplaces by means of expert evaluation method. Surveying the experts has helped us confirm the trend (for 2015-2018) of Ukraine-EU cargo transportation redistribution. Also, it has been determined that $73 \%$ of our respondents are using DFEs on a daily basis. The following factors have been found to be the most influential in relation to the activities of transportation marketplaces: further growth of expeditionary activities, reorientation on European countries, rapid development of the related Internet technologies and overall automation of cargo transportation process. Prospects in future development of transportation marketplaces have been defined along with the expectations of the leading representatives at the market of cargo road transportation. This article contributes to the development of knowledge in the field of freight transport logistics, namely, the

${ }^{1}$ Candidate of Economic Sciences,

Associate Professor at Department of Transport Law and Logistics,

National Transport University, Ukraine 


\section{Chapter «Economic sciences»}

development of the concept formation of freight exchange platforms, depending on the needs of consumers and the digitization of the transport services market.

\section{Introduction}

«In recent years, technology startup firms have created a new kind of rental market, in which owners of the assets sometimes use their assets for personal consumption and sometimes rent them out. Such markets are referred to as peer-to-peer ( $\mathrm{P} 2 \mathrm{P})$ or «sharing economy» markets. Companies based on the sharing economy concept, such as Uber and Airbnb have shown spectacular growth over the last couple of years and have generated an ongoing debate about how to regulate them. This has drawn the attention of regulators to businesses that are using the Internet and mobile technology to create marketplaces or assignment mechanisms that match up disparate buyers and sellers. These businesses can be witnessed across a broad swath of industries» has been spoken in the article by M.P. Jaiswal, Parul Gupta, Prageet Aeron, Rajeev Gupta (2014). Nowadays in the transportation fields sharing economy concept is known such P2P transport platforms like Uber Freight, Lyft, Blablacar, Didi Kuaidi. Consequently, understanding that intelligent transport systems (ITS) in the new era of digitalization should be suitable for both private customers and companies requests deeply research about current activities and new opportunities, taking into the types of users and the country to which their business is focused. This question is becoming more actual because the data of Eurostat has shown redistribution of a proportion of the national and international road transport of goods. The split between national and international road freight varied considerably across the Member States. In 2016, the highest proportions of national road freight transport were recorded in Cyprus (97.3\%) and the United Kingdom (96.4\%), while shares in France, Sweden and Finland were also above $90 \%$. By contrast, thirteen of the Member States reported that the majority of the goods transported by vehicles registered in their Member State had taken place on foreign road networks. The share of international road freight transport in total road freight was particularly high in Lithuania (90.4\%), Slovenia (88.6\%), Luxembourg (87.2\%), Slovakia (84.2\%), and Latvia (80.3\%). In this context, it is advisable to explore the most interesting platforms (apps) 


\section{Horbenko Alexandra}

for users, their capabilities in terms of financial control, cargo insurance, and contract authentication.

Consequently, the trend of redistributing the share of national and international road transport of goods requires the offering of various activities and capabilities of the platforms so that users can work effectively with it in different countries. Talking about digitalization in the transport field, usually, mean Intelligent Transportation Systems (ITS) which work on business-to business market. ITS includes: e-maps, car navigation systems and Vehicle Information and Communication System (VICS), have based on GPS; digital freight exchanges (DFEs), electronic tags and Dedicated Short Range Communication (DSRC) systems; special apps for exchanging the information between platform's customers. Each of these technological advances will develop in its own way.

In the research Dr. Gerhard Nowak "The era of digitized trucking. Transforming the logistics value chain" was noticed the six technological advancements that will transform trucking and logistics before 2025 . There will be Vehicle-to-infrastructure (V2I) communication, Vehicleto-vehicle (V2V) communication, Remote diagnostics, Autonomous driving, Integrated supply chain and Automated freight matching. If V2I, $\mathrm{V} 2 \mathrm{~V}$, remote diagnostics and autonomous driving are the technologies of the future, integrated supply chains and automatic freight matching will take place now. Dr. Gerhard Nowak talks that «thanks to their ability to communicate with fleet management and with shippers of goods - and in the future with cloud-based solutions for freight matching - trucks will eventually be able to determine whether they can take on additional freight. The truck trailer itself will be able to determine through sensors its available space and weight, as well as scheduled route, ETA, and other relevant information, and communicate this data to a digital freight-matching platform» (Presence of Uber).

A freight exchange platforms (sometimes known as apps for transport exchange) are the tool for facilitating the exchange of information between shippers and consignees on the process of cargo transportation, with the possible support services such as insurance and financing, and has presented in the form of online resources.

There are not many studies based on official sources or highly specialized information, which describes the TOP DFEs, the type of users these freight exchange platforms, their activities and opportunities. 


\section{Chapter «Economic sciences»}

\section{Literature review}

Market conditions research is a continuous process. Such studies in Ukraine are of a one-time nature and carried out by commercial agencies for the customers. We have only separate notes in the business magazines about digital instruments, which can be used by transport companies. Hence, authors consider it incorrect to indicate a wide range of works that indirectly relate to the digital market in the logistics fields (Bilan et al., 2017). There are lot of authors (Andersson, Hjalmarsson \& Avital, 2013; Amit Tiwari \& Rajan, 2014; Badzińska, 2016; Bakhtieva, 2017; Balcerzak \& Pietrzak, 2017; Crainic, Gendreau \& Potvin, 2009; Jaiswal \& Gansky, 2010; Karpenko, Horbenko, Vovk \& Tson, 2017; Kiba-Janiak, 2014; Kovács \& Kot, 2017; Nemoto, Visser \& Yoshimoto, 2001; Nwaiwu, 2018; Sulkowski \& Kaczorowska-Spychalska, 2018; Velychko, 2015; Visser, 2003; Yoshimoto \& Nemoto, 2005; Zielińska, Prudzienica, Mukhtar \& Mukhtarova, 2016; Zimon, 2018;), which have been working in this way. For example, Ryuichi Yoshimoto and Toshinori Nemoto in their survey from 2005 say that e-commerce changes the supply chain (Yoshimoto \& Nemoto, 2005; Nemoto, Visser, \& Yoshimoto, 2001). As a result, information and communication technologies, particularly the growth of the Internet and Intelligent Transportation Systems (ITS), are having a variety of effects on logistics systems (Bauk et al., 2017; Kot, 2015). New wave of the results has appeared during introduction of Industry 4.0 tools to logistics practice (Ślusarczyk, 2018). Such effects can be divided into three categories:

1. The Internet increases B2B and B2C transactions, leading to greater transportation demand (e-commerce).

2. The Internet and ITS create more sophisticated markets for L2S and L2L transactions and promote freight consolidation (e-logistics).

3. ITS promotes optimization of fleet management based on traffic and other real-time information, leading to better transportation efficiency (e-fleet management).

In the same time Crainic, Gendreau, Potvin (2009) classified these systems in two broad classes: Commercial Vehicle Operations (CVO) for system-wide, regional, national or continental applications and Advanced Fleet Management System (AFMS) dedicated to the operations of a particular firm. Ukraine began her steps in process of joining to the EU only last few year. So, in Ukrainian studies there is no detailed information on the type of users of freight exchange platforms, their popularity in Ukraine, 


\section{Horbenko Alexandra}

the division of companies according to the geography of their activities, the frequency of use of cargo stock exchanges.

\section{Research methods}

The identified resources cover several types of interrelated disciplines, including marketing, management, supply chain management, and logistics. Due to the lack of precise keywords defining the topic, the authors make considerable efforts to sort scientific and industry journals. As a rule, this step can be performed by concentrating on well-known magazines and conferences. Nevertheless, the topic of digitization in the transport sector is new. Therefore, the following main online databases were used to search for information about this: Scopus Elsevier, Web of Science Thomson Reuter, and ScienceDirect (Elsevier). This search showed that the concept of digital freight exchanges (DFEs) is still in the early stages of research and development among scientists, although it is widely recognized and discussed among practitioners.

It should be noted that in this study the companies of the following fields of activity were represented: manufacturing (manufacturing companies), distribution (companies providing services for the distribution of goods), trade (trading companies, including retail), transport (companies owning parking and lease it to other companies), expeditions (freight forwarding companies in accordance with applicable law). However, in the course of the survey, some companies indicated their activities as a logistics operator, since they operate on the verge of various spheres. Therefore, an additional score of 3PL. Recall that the well-known classification of companies providing logistics services, 1PL - 5PL still causes controversy due to the lack of definitions in the legislation. However, for this study, we left the company in this area of activity. Nevertheless, more and more users ( $46 \%$ of respondents) are positioning themselves and, accordingly, belong to freight forwarders.

The survey involved 186 companies that actively use trucks. The study took 4 months: during this time, responses to the questionnaire were collected and interviews were conducted with the directors of the main platforms of transport exchanges, which were revealed when interviewing users of this type. It was found there is a wide range of freight exchange platforms from:

- from general to specialized, such as Tona.com.ua, which provides transportation services for apartment and office moving, transportation of pets, household appliances, furniture, etc. 
- open to conditionally closed companies that have a small number of users, but which are large companies or holding companies, such as: Boards, whose main pool of client base consists of large corporate clients, such as Metinvest, Interpipe, Khortitsa, etc.

The questionnaires included 5 basic questions for users of transport platforms. During the online survey, answers were received from transport companies, which make the largest contribution to the volume of traffic in Ukraine.

Interviews with the directors of the platforms were conducted in a personal format, during which the main activities of the platforms were identified, as well as the opportunities that they provide to consumer companies. Speaking of opportunities, this implies the quality of the digitization platform (application) with information about contracts, freight forwarders, consignees, problems with cargo insurance, liability for loss of cargo during delivery.

In general, the research base is based on the results of field studies (questionnaires, mail polls and personal interviews), as well as information from various sources (in particular, Eurostat and the State Statistics Committee of Ukraine). According to open sources of the State Statistics Committee of Ukraine, an analysis was made of the volume of freight traffic, which showed annual growth. Due to the fact that there is no research in the Ukrainian market about the digitization format used by transport companies in their activities, the authors conducted a survey of transport and logistics companies.

\section{Research results}

Freight exchange platforms, as resources for the exchange of information, can be divided by transport modes: road (freight), air, water and rail transport. Their functionality varies due to the specifics of transport, state regulation and the number of participants. Maersk, Track-trace, Searates, Marine traffic, Shipau are widely known systems of water transport. Such systems allow tracking the current position of the container on a Google map. To get information about the location of containers it is enough to enter its number and shipping line. In addition, you can get information on trans-loading ports and transit time. The systems of rail transport are the Wagon Info service, Railwagonlocation, Seedrail and others. They show the movement of cars and cargo online: integrate information about 


\section{Horbenko Alexandra}

the movement of cars and present it in a form for analysis on individual web pages of the site; have baseline data on operations with cars, which regularly comes from the information network of railways of Ukraine, other CIS countries and the Baltic. On air transport, one can also track cargo with a bill number by entering it to the search box on relevant sites such as ceni-com.com, union-cargo.com or avia78.ru.

Freight forwarding activity in Ukraine is carried out by economic subjects of various forms of ownership, which, in order to fulfill the orders of customers or according to the technology of work, may have: warehouses, various types of vehicles, containers, industrial premises, etc. (On Freight Forwarding Activity, 2014). Freight forwarders can enter into contracts with carriers, ports, airlines, shipping companies, etc., which are residents or non-residents of Ukraine. Freight forwarding activities can be carried out both by specialized enterprises (organizations) and other economic entities. Freight forwarding services are provided to a customer for export from Ukraine, import into Ukraine, transit through the territory of Ukraine or other states, domestic transportation through the territory of Ukraine. In general, there are almost 56.2 thousand carriers operating in the market of commercial transport at that time, which use more than 154 thousand vehicles in their activities.

The trend of the last four years is in the retargeting of road freight transportation of Ukraine to EU countries. This is also evidenced by survey data (Figure 1).

In the study carried out by the authors the exchanges of freight road transport in Ukraine are considered. Currently, there are 19 well-known freight exchange platforms in Ukraine. They include not only domestic platforms, but also platforms from other countries. The poll has shown that the most famous are Lardi Trans.com, Della.ua, Trans.eu, Degruz.com, Cargo.lt, Timocom.ru, Stascom.com, A2b.direct, Transporeon.com, Ati.su, Sit-trans.com, Sovtes.ua, Tona.com.ua, Logistoffice.com, Transport.md, Logintrans.ru, Transinfo.by, Avtodispetcher.ru, and Transport.totalsystem.md. (Figure 2).

It should be noted that some platforms that do not get a single vote do not mean that they are useless. For example, Sovtes is a type of closed platform that only corporate users can work, since the owner of this platform is a holding. Another type of open platform is Tona, which was mainly used by people (not companies) to move office furniture and individual items. As noted earlier, the survey was conducted between carriers operating in the 


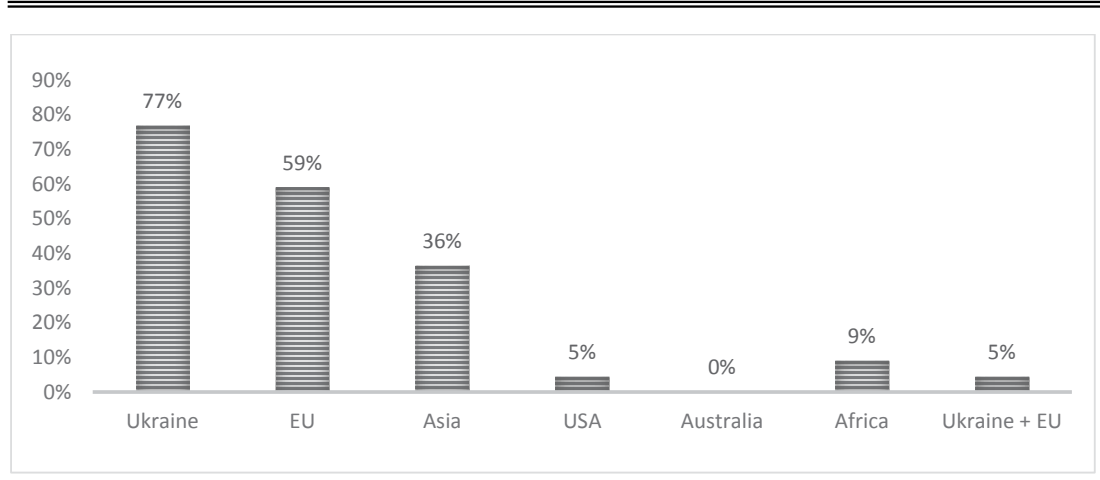

\section{Figure 1. Division of companies by geography of their activities [\%]}

Source: author's elaboration on the basis of poll: TOP-5 transport exchanges in Ukraine, 2018

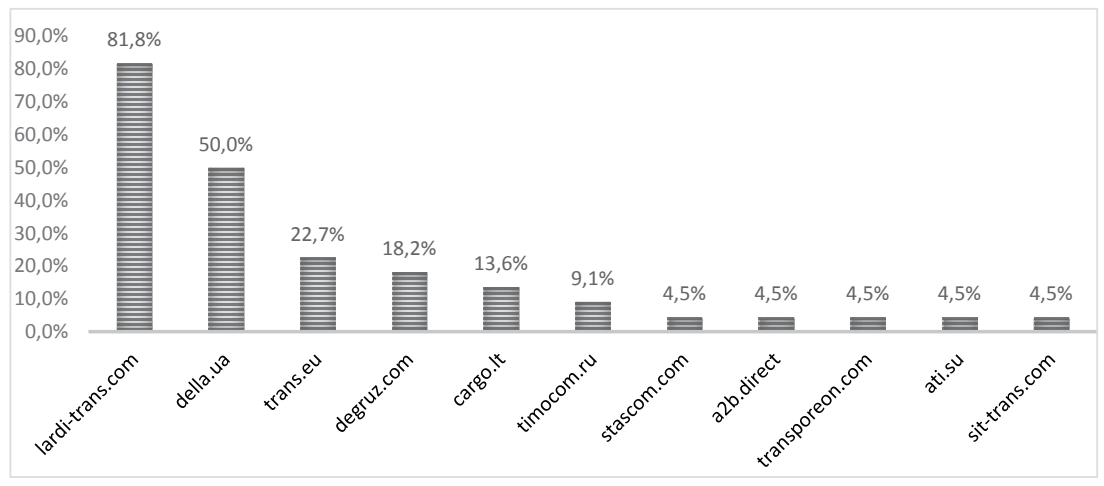

Figure 2. Freight exchange platforms in Ukraine by popularity [\%]

Source: author's elaboration on the basis of poll: TOP-5 transport exchanges in Ukraine, 2018

commercial vehicle market and using their own vehicles in their activities or simply renting them, therefore some of the Ukrainian platforms did not receive a single vote, or just one.

At the same time, it was found out most users of freight exchange platforms are registered and made their business on several platforms at once. Among the Ukrainian platforms, Lardi, Della and Degruz are popular. The main users of the services of transport exchanges are freight forwarders (Figure 3). 


\section{Horbenko Alexandra}

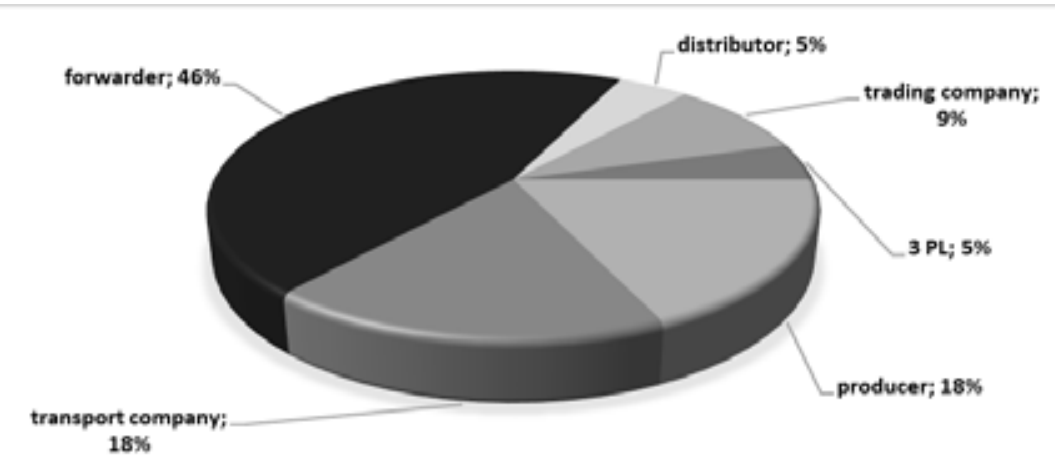

Figure 3. The type of users of freight exchange platforms [\%]

Source: (Poll: TOP-5 transport exchanges in Ukraine, 2018)

Each platform has its own user ratio. For example, in DeGruz, according to Mykola Shevchenko, head of the company, the main positioning of the exchange is the work with major customers: direct shippers, that is, companies that own the goods, as well as the owners of vehicles - direct carriers. Subsequently, other types of users getting to work with a platform. To date, the ratio of users of the DeGruz Exchange: 80\% (major customers) $20 \%$ (expedition, producer, trading company).

For today, it is impossible to imagine a daily planning without freight exchange platforms. Study data confirm this: $73 \%$ of the respondents use the transport platforms daily in their business activities (Figure 4).

In order to determine which platforms to work with, it is advisable to compare their declared opportunities, the number of registered users, the cost of placing requests, the level of security, the geography of activities, the possibility of digitization (mobile applications).

At first glance, the choice of the appropriate transport exchange is simple: the more registered users, the more opportunities to find transport and the consumer. However, there is still a misunderstanding of the concept of «user». Therefore, some transport exchanges deliberately or not, show the number of offers in such a way that is identified with the number of all users. However, a potential user can independently determine the attendance level of a particular transport exchange on its website, or by reviewing the data on resource rating sites such as bigmir.net, etc. When choosing a transport 


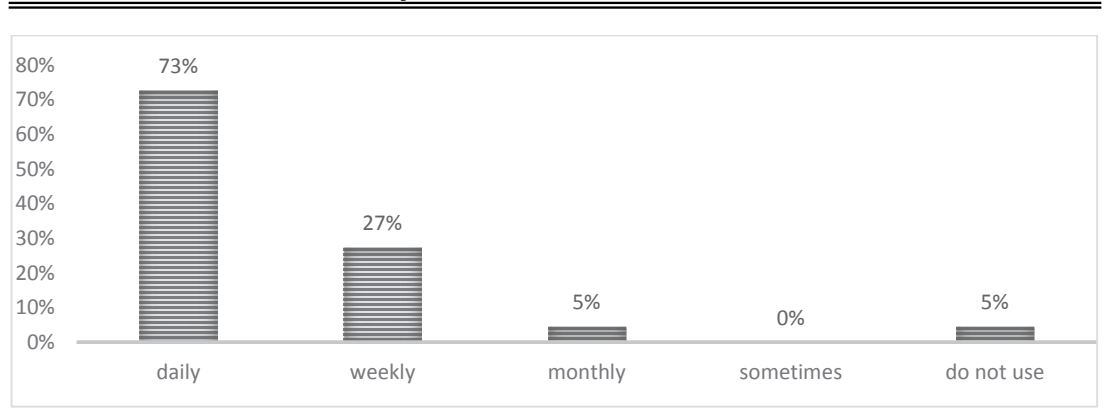

Figure 4. Frequency of freight exchange platforms use [\%]

Source: the author's development from poll: TOP-5 transport exchanges in Ukraine, 2018

exchange, in addition to the number of offers, the reliability of potential business partners also plays a decisive role. The wider the security package offered by the exchange, the more difficult it is for unscrupulous users to conduct their dishonest activity.

\section{Discussion of the results}

Further growth of expeditionary activity, reorientation to Western countries, development of Internet technologies and general automation of cargo transportation process will facilitate the development and transformation of transport exchanges.

According to Roland Berger's poll in 2016 (Roland Berger, 2016), the digitization in logistics will happen faster than in other industries. Ignoring this trend could result in losses of about 605 million EUR. More than $50 \%$ of the respondents believe that digitization will radically change the logistics industry.

Almost every transport exchange already has mobile applications. Maksym Golovenko, LogIntern Ukraine LLC, says that digitalization in the field of freight transportation has long come, but not everyone succeed in this trend. The companies of the freight transportation sector, which adapted to innovations, are a step ahead of their competitors. At the moment company has created 6 mobile applications. The most popular are TransExpress (search of cargo on a smartphone), TransParking (search of free parking for trucks) and TransMessenger (our unique business communicator in the mobile version). Another participant of the poll confirms his words. According to 
Top 5 freight exchange platforms in Ukraine

\begin{tabular}{|c|c|}
\hline NAME & ACTIVITIES \\
\hline TimoCom & $\begin{array}{l}\text { There is an option for a 4-week free-of-charge use without limiting access } \\
\text { to all services: eMap (navigation), counterparties profile, tenders. In order } \\
\text { to register on the exchange, one need to provide a license, a tax reference, } \\
\text { a certificate of registration, a carrier or forwarder insurance, scans of } \\
\text { documents of the company owners. If the company operates in the market } \\
\text { for less than } 6 \text { months, then it will not get access to the platform. Timocom } \\
\text { also has the Timocom CashCare section, which allows the exchange to ask } \\
\text { for help in litigation with the customer or carrier. }\end{array}$ \\
\hline Trans EU & $\begin{array}{l}\text { At the end of 2016, 34,800 companies worked in the system of Trans. } \\
\text { eu based on permanent contract. Trans.eu users have over } 210,000 \\
\text { offers per day. The average annual increase is } 25 \% \text {. The cost of annual } \\
\text { access is EUR } 828 \text {. There are } 7 \text { days of trial period. Services include } \\
\text { offer exchange, business messenger, road maps, integration with GPS- } \\
\text { provider, TransExpress and TransParking mobile applications. Cargo } \\
\text { types in the system are different: oversized, ADR, perishable. }\end{array}$ \\
\hline Della & $\begin{array}{l}\text { The resource is available in all CIS countries. Just add the domain of a } \\
\text { country, such as .by; .ru; . ua; . kz; . az in the site's name della, and you can } \\
\text { find cargo in a single CIS country. An interesting service function is the } \\
\text { tracking of price offers for freight within each country, as well as popular } \\
\text { international connections. However, many offers of goods and transport on } \\
\text { the stock exchange are duplicated from other exchange transport platforms }\end{array}$ \\
\hline Degruz & $\begin{array}{l}\text { Ukrainian exchange, founded in } 2006 \text {. Number of registered companies, } \\
\text { as well as private entrepreneurs, more than } 90,000 \text {. Every day, } 70 \text { new } \\
\text { companies are registered. The exchange operates mainly with direct } \\
\text { cargo owners, the number of offers starts from } 7,000 \text { per day, depending } \\
\text { on the season. To get started, you need to provide scans of documents. } \\
\text { All information and services on the website are free for users, except for } \\
\text { contacts of cargo owners. Access to the contacts of the cargo owners is } \\
\text { EUR } 3-4 / \text { month; it all depends on the chosen period of payment and the } \\
\text { type of user. The popular exchange services include access to cargo and } \\
\text { free transport requests, catalog of cargo owning companies. In addition, } \\
\text { the exchange contains a calculation of the cost of transportation, statistics } \\
\text { of prices, and calculation of distances. }\end{array}$ \\
\hline Lardi-trans & $\begin{array}{l}\text { Ukrainian exchange, which is popular among the carriers of the CIS } \\
\text { countries. More than } 100,000 \text { accounts is registered on lardi-trans.com. } \\
\text { A year ago, there were } 7 \% \text { less of them. Every day more than } 50,000 \\
\text { requests for the carriage of goods and offers of free transport are placed } \\
\text { on the site of the company. Registration and placing of requests on the } \\
\text { site is free, and the minimum cost of access to contact information on } \\
\text { requests within Ukraine is USD 5-6. The free trial week is available for } \\
\text { companies from Russia and Belarus. Search services for requests for } \\
\text { cargo transportation and free transport; Reliability zone, which consists } \\
\text { of both reviews and ratings of companies, as well as advertising on the } \\
\text { site, since website traffic is more than } 3 \text { million people per month. The } \\
\text { exchange works with all the goods that can be transported by road. To } \\
\text { start work on the site a regular registration is required, when the user } \\
\text { specifies his contact details and the state registration form }\end{array}$ \\
\hline
\end{tabular}

Source: the author's development 


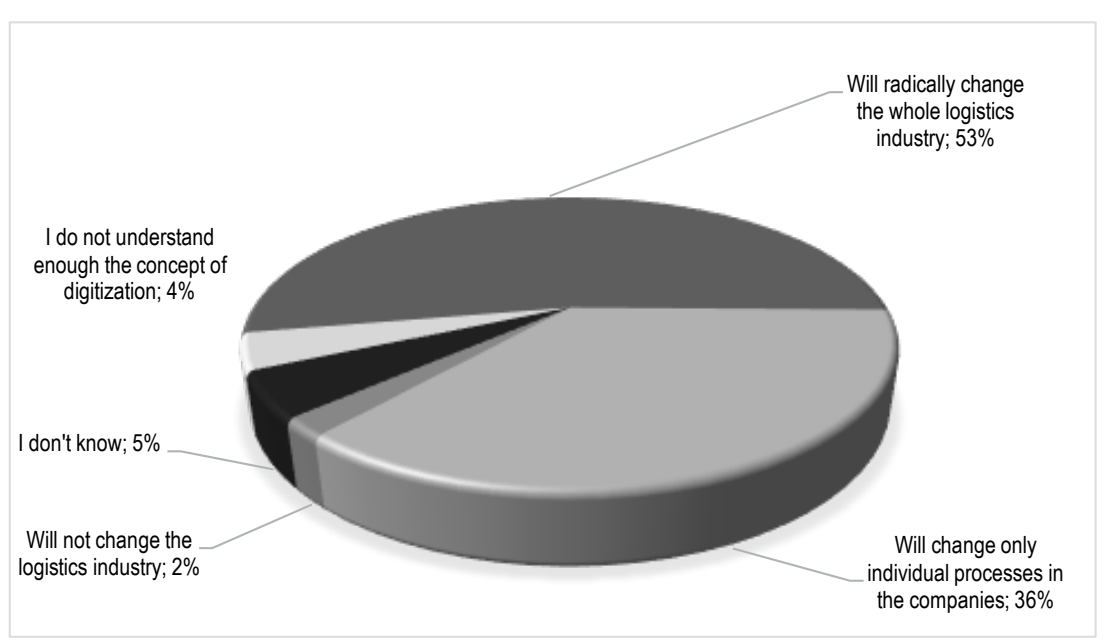

Figure 5. Influence of digitalization on logistics [\%]

Source: Roland Berger Study: End-game in innovative logistics, 2016

Dmytro Brusilovskyi, Lardi-Trans, thousands of carriers use daily the larditrans.com application on mobile devices working on iOS and Android.

In general, there are many mobile applications for freight road transport. For example, MyFuel service, which allows oil consumers to jointly purchase fuel from various petrol stations that have become partners in the service (Nefterynok, 2014).

Total digitization also provokes the emergence of new services for the transport sector like Uber freight. According to Dmytro Brusilovskyi from LardyTrans, the main tendencies should be not so much uberization, but divergence. Uberization is an attempt to introduce a cargo transportation mechanism that proved its efficiency in passenger transportation and provides creation and transfer of orders to the performer on one platform in an online mode. In his opinion, Uber Freight cannot compete with transport sharing platforms so far as cargo transportation is a multi-stage process in which many companies take part and these are not always mediators that could be safely eliminated. Cargo transportation, except for the simple movement of goods from point A to point $\mathrm{B}$, includes loading, unloading, warehousing operations, document circulation, financial transactions and much more. It is possible to automate these steps only to a certain extent, and then you will still need human involvement. 


\section{Horbenko Alexandra}

The words of Maksym Golovenko from Logitrans Ukraine, the official representative of Trans.eu, coincide with such an opinion: "You cannot predict the result of the direct work with a private driver, on the one hand, the price of transportation is optimized, and on the other - the risks increase».

"The idea of the freight Uber is not new, we are seeing such trends in the CIS market for more than 3 years, there periodically appear platforms with a similar format of work,» - says Mykola Shevchenko, DeGruz. «However, the Ukrainian market is quite conservative in relation to both new types of services and new operators. Tthe number of leading exchanges for the Ukrainian market is quite large. I believe that the services will probably be changed over time on existing platforms».

Another important trend is the divergence of IT products, as the era of «industry solutions» now comes. To some extent, an automotive company can make do with a bundle of CRM systems, Google documents, corporate chat, GPS tracking and accounting. However, the growth of such a company will be largely restrained by the need to work with different data in different systems. Competitors who are able to aggregate information and process it faster will be more successful. That's why Lardy-Trans, for example, develops not only the basic function of «exchange» or bulletin board, but also consistently develops the so-called value added products, which include services for work with fleet and cargo from the client's office, GPS tracking, cargo and transport insurance, counterparty checking and conclusion of contracts.

The next trend that experts distinguish is the creation of «transport aggregators,» that is, those services that maximally automate the process of finding orders, calculating the cost, optimizing routes and minimizing intermediary man-hours. Such services include Cargo BR, Keychain, Kwanji, One more pallet, Runner, Scurri, ShipHawk, etc.

Stakh Wozniak, director of Tona.com.ua, analyzed the experience of Uber, Lyft, Gogovan, Cargomatic and created a wider functional than the transport exchange and aggregator - Cargofy.com (Transport aggregator, 2018). The aggregator is available in Ukraine, USA, and India. The aggregator automatically responds to the order for transportation, selects the nearest free carriers with the appropriate body type and notify them. One of the carriers accepts orders for execution in 5 minutes on average. Tracking of all deliveries occurs in real-time on the map, routes are automatically generated and there are also notifications of changes in delivery status. In addition, the 


\section{Chapter «Economic sciences»}

algorithm analyzes the free space in the body of the truck and allows you to send the goods by concomitant transport, significantly saving on delivery. That is, transport aggregators are a possible next step in the transformation of transport exchanges, the development of which takes place both on the basis of transport exchanges and on the basis of CRM products (Rudkovsky, 2015): iCanDeliver, ABMRinkai, 4Logist, Skyriver, Sovtes, Rational Logistics, the functional review of which still requires special attention.

The Ukrainian freight transport market is rather conservative and traditional, so it's too early to talk about widespread digitization and uberization for Ukraine, much will depend on the Internet $-4 \mathrm{G}$ does not yet have a good coverage, not to mention $5 \mathrm{G}$.

\section{Conclusions}

We can accord with the authors Amit Tiwari, Udava V. Rajan and their notices in the article «Intellectual Infrastructure Development in the Era of Information Society» in the part that any organization consists some of the infrastructural hierarchies. Their studies have found that half of the professionals spend more than 2 hours per day looking for the right and relevant information rather than using them. Same to the transport sector, because there are terrific massive information in different places (apps, platforms) and customers waste time to find out correct and current news in the informational noise (Becla, Czaja \& Zielińska, 2010). According to our research and optimistic data by Roland Berger (Roland Berger, 2016), future players in logistics can be represented in four groups:

1. Booking and optimization platforms - independent platforms for managing logistics operations with route and cost optimization opportunities.

2. Carriers and terminal operators - owners of assets that perform logistics operations with high efficiency in managing expenditures and assets with a clear specialization (standardization).

3. Supply chain specialists - companies that provide integrated solutions, solve specific tasks in the branch supply chain.

4. Service providers - companies providing support services for logistics companies and solutions.

However, like each it-product from sharing economy the transport platforms need to be law. This is why many companies (especially in Ukraine) create such platforms only for their customers, pulling them into united network. 


\section{Horbenko Alexandra}

\section{References:}

1. Presence of Uber Freight and Other Players Raises the Stakes for Truckload Brokerage. URL: https://www.mmh.com/article/presence_of_uber_freight_raises_ the stakes for truckload brokerage

2. Andersson, M., Hjalmarsson, A. \& Avital, M. (2013). Peer-to-peer service sharing platforms: Driving share and share alike on a mass-scale. ICIS2013.

3. Baron, R., Zieris, M., Zintel, E. \& Mikulla, D. (2017). Study: Digital platforms in freight transportation. Retrieved August 2017 from: http://www.adlittle.com.

4. Bauk, S., Kapidani, N., Schmeink, A. (2017). On Intelligent Use of ICT in Some Maritime Business Organizations. Montenegrin Journal of Economics, 13(2), 163-173.

5. Crainic, T.G., Gendreau, M. \& Potvin, J. Y. (2009). Intelligent freighttransportation systems: Assessment and the contribution of operations research. Transportation Research Part C: Emerging Technologies, 17(6), 541-557.

6. Gansky, L. (2010). The mesh: Why the future of business is sharing. Penguin.

7. Jaiswal, M.P. (2014). Draft Policy Recommendations for Application Based $\mathrm{Cab}$ Aggregators (ABCA) in India.

8. Kargolink Exchange (2015). Overview of European transport exchanges. Retrieved April 26, 2015 from https://cargolink.ru/ls/blog/1288.html

9. Karpenko, O. (2015). Smart logistics: The Kyiv team created software for carriers, capable of saving millions. Ain.ua. Retrieved April 30, 2015 from: https://ain.ua/2015/04/30/logistika-s-umom-kievskaya-komanda-sozdala-softdlya-perevozchikov-sposobnyj-ekonomit-milliony

10. Kot, S. (2015) Cost structure in relation to the size of road transport enterprises, Promet - Traffic - Traffico, 27(5), 387-394. doi: 10.7307/ptt.v27i5.1687

11. Kovács, G., Kot, S. (2017). Economic and social effects of novel supply chain concepts and virtual enterprises. Journal of International Studies, 10(1), 237-254. doi: 10.14254/2071-8330.2017/10-1/17

12. Moreira, F., Ferreira, M.J. \& Seruca, I. (2018). Enterprise 4.0-the emerging digital transformed enterprise? Procedia Computer Science, 138, 525-532. doi: 10.1016/j.procs.2018.10.072

13. Nefterynok (2014). ULTRA / MANGO and MyFuel service launched a system for group purchasing fuel on the Internet with a discount. Retrieved April 20, 2014 from: http://www.nefterynok.info/uk/novini/ultra--mango--servs-myfuelzapustili-sistemu-grupovo-pokupki-paliva-v-nternet-z-znijkoyu

14. Nemoto, T., Visser, J., Yoshimoto, R. (2001). Impacts of information and communication technology on urban logistics system. Working Paper, No 65. Hitotsubashi Univ.

15. Nowak, G., Maluck, J., Stürmer, Ch., Pasemann, J. (2016). Study: The era of digitized trucking: Transforming the logistics value chain. Retrieved September 16, 2016 from: https://www.strategyand.pwc.com/media/file/The-era-of-digitizedtrucking.pdf

16. Nwaiwu, F. (2018). Review and Comparison of Conceptual Frameworks on Digital Business Transformation. Journal of Competitiveness, 10(3), 86-100. doi: $10.7441 /$ joc.2018.03.06 


\section{Chapter «Economic sciences»}

17. Poll: TOP-5 transport exchanges in Ukraine. (2018). Retrieved October 15 , 2018 from: https://docs.google.com/forms/d/e/1FAIpQLSd--5syjlc6o9o67U7033y WvG60WJV9hwkpaJcqgT-pe-3wrQ/viewform?usp=sf_link

18. Roland Berger (2016). Study: End-game in innovative logistics. Moscow 2016. Retrieved October 15, 2018 from: https://www.rolandberger.com

19. Rudkovsky, O. (2015). 6 services for transportation. Rusbase. Retrieved November 24, 2015 from: https://rb.ru/opinion/logistics-and-it/

20. State Statistics Service of Ukraine (2016). Statistical Digest of Ukraine in Figures 2016. Publication of documents of the State Statistics Service of Ukraine. Retrieved October 15, 2018 from: http://www.ukrstat.gov.ua/

21. Sulkowski, L., Kaczorowska-Spychalska, D. (2018). Internet of Things New Paradigm of Learning. Challenges for Business. Advances in Neuroergonomics and Cognitive Engineering Proceedings of the AHFE 2018 International Conference on Neuroergonomics and Cognitive Engineering. Springer, Cham, 307-318.

22. Tiwari, A., Rajan, U.V. (2016). Intellectual Infrastructure Development in the Era of Information Society.

23. Transport aggregator. (2018). Retrieved October 15, 2018 from: https://cargofy.com

24. Uber Freight (2018). Retrieved October 15, 2018 from: https://freight.uber.com

25. Velychko, O. (2015). Logistical system Fortschrittzahlen in the management of the supply chain of a multi-functional grain cooperative. Economics \& Sociology, 8(1), 127-146. doi: 10.14254/2071-789x.2015/8-1/10

26. Visser, J. (2003). E-commerce and the consequences for freight transport. Innovations in freight transport. WIT press. 